\title{
TOWARDS AN RRG ANALYSIS OF CONSTRUCTIONS WITH A MORPHOLOGICAL CAUSATIVE IN SOME ALTAIC LANGUAGES
}

\author{
Valeria Generalova*
}

\begin{abstract}
The present paper examines Bashkir and Kalmyk construction formed from transitive verbs by means of causative suffixes ${ }^{1}$. We refer to these constructions to "constructions with a morphological causative". The paper also references other Altaic languages (Mishar Tatar, Nanai, Tuvinian, Khakas). The main focus of the paper is on the valence-increasing behavior of causatives. Primary attention is drawn to the case marking of the Causee since Altaic languages allow several options for that. The paper describes in detail the existing alternation and reviews prior explanations of this phenomenon. It then couches the explanation for the alternation within the framework of Role and Reference Grammar. The analysis identifies that Altaic constructions in question are somehow peculiar compared to general trends. After discussing the advantages and drawbacks of various theoretical interpretations of this peculiarity, we conclude that it is best to link two different causative constructions to two different logical structures. We also suggest constructional schemata for Kalmyk and Bashkir to include in the Linking Algorithm.
\end{abstract}

Keywords: causative, RRG, case assignment, frame semantics.

\section{Introduction}

\subsection{Role and Reference Grammar and its Linking Algorithm}

This section aims to give an overview of the most relevant concepts of Role and Reference Grammar (RRG). As Figure 1 shows, there are two principal components in RRG: the syntactic representation and the semantic representation. The former is realized as a tree grammar. In the present paper, we are not going deep into the details of how syntactic representations are created, but, when necessary, we use the version formalized by Osswald \& Kallmeyer (2018).

\footnotetext{
* Heinrich Heine University of Düsseldorf, generalo@hhu.de. This work is part of the TreeGraSP project funded by an ERC Consolidator Grant awarded to Prof. Laura Kallmeyer. I express my deepest gratitude to E. V. Perekhval'skaya and A. S. Smetina for sharing their fieldnotes with me. I am also grateful to two anonymous reviewers for their helpful comments.

${ }^{1}$ Abbreviations: 1 = first person, $3=$ third person, $\mathrm{ABL}=$ ablative, $\mathrm{ACC}=$ accusative, $\mathrm{CAUS}=$ causative, $\mathrm{DAT}=$ dative, DET $=$ determiner, EX $=$ non-semantic stem extension, GEN $=$ genitive, INF $=$ infinitive, INS $=$ instrumental, $\mathrm{IPFV}=$ imperfective, $\mathrm{LOC}=$ locative, $\mathrm{M}=$ masculine, $\mathrm{NOM}=$ nominative, $\mathrm{PASS}=$ passive, $\mathrm{PL}=$ plural, $\mathrm{POSS}=$ possessive, $\mathrm{PROG}=$ progressive, $\mathrm{PRS}=$ present, $\mathrm{PST}=$ past $\mathrm{PTCP}=$ participle, $\mathrm{REFL}=$ reflexive, $\mathrm{SG}$ $=$ singular, $\mathrm{ST}=$ derived stem.
} 


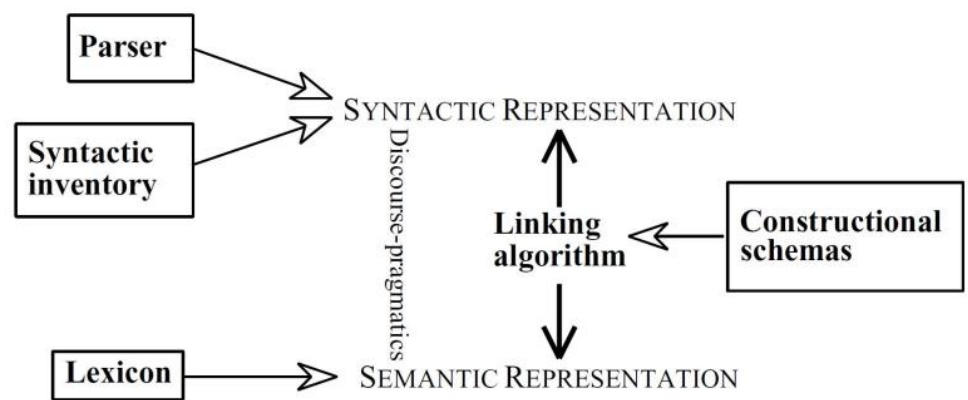

Figure 1. Organization of Role and Reference Grammar (Van Valin Jr. 2005, Figure 5.4)

The semantic representation has more importance for our study. In RRG, semantic representations of sentences are realized in predicate logic. Verbs are represented as predicates and the participants - as arguments. There are also some additional predicates in the logical structures (LS) that characterize the events described by the verbs. The RRG system is based on the Aktionsart scheme but has been enriched with new verb classes. All of them are listed in Table 1. The first thing to note is that the RRG verb class system allows two kinds of basic predicates: intransitives and transitives. There are six main classes, each having a corresponding logical structure. Causatives are also listed in the table (see the last line of Table 1), but they are described differently.

According to Van Valin Jr. (2005), a verb belonging to any class may enter a causative alternation. Therefore, there is one general formula for causative events. It comprises the CAUSE operator, which can take a logical structure of any kind on either side. In particular, it means that the causing event and the caused event can be of different types (which is the case in most languages). We appreciate this about RRG that it tends to be sensitive to typologically varied data.

In the RRG architecture, the semantic representation and the syntactic representation are not totally independent. There is a specific structure called the Linking Algorithm (LA) to connect them. As it is at the center of our analysis, we would like to go into more detail about it.

The Linking Algorithm (LA) is described in Van Valin Jr. (2005: Ch. 5), in the form of procedural steps. It is actually a set of guidelines for someone who would like to link a syntactic structure to a semantic one or vice versa. The term "linking" refers to the procedure of determining which argument of the logical structure corresponds to which syntactic unit. The algorithm can operate in both directions (semantics-to-syntax and syntax-to-semantics). The necessary steps are identical, but the sequence of guidelines is somewhat different (Van Valin Jr. 2005: 136, 149). 
Table 1: Representations of verb classes (reproduced from Van Valin Jr. 2005, Table 2.3)

\begin{tabular}{|c|c|}
\hline STATE & $\operatorname{predicate}^{\prime}(\mathrm{x})$ or $(\mathrm{x}, \mathrm{y})$ \\
\hline ACTIVITY & do $^{\prime}\left(\mathrm{x},\left[\operatorname{predicate}^{\prime}(\mathrm{x})\right.\right.$ or $\left.\left.(\mathrm{x}, \mathrm{y})\right]\right)$ \\
\hline ACHIEVEMENT & $\begin{array}{l}\text { INGR predicate }(x) \text { or }(x, y) \text { or } \\
\text { INGR do } \text { do }^{\prime}\left(x,\left[\text { predicate }^{\prime}(x) \text { or }(x, y)\right]\right)\end{array}$ \\
\hline SEMELFACTIVE & $\begin{array}{l}\text { SEML predicate }(x) \text { or }(x, y) \text { or } \\
\text { SEML do } \text { do }^{\prime}\left(x,\left[\text { predicate }^{\prime}(x) \text { or }(x, y)\right]\right)\end{array}$ \\
\hline ACCOMPLISHMENT & $\begin{array}{l}\text { BECOME predicate }(x) \text { or }(x, y) \text { or } \\
\text { BECOME do }^{\prime}\left(x,\left[\text { predicate }^{\prime}(x) \text { or }(x, y)\right]\right)\end{array}$ \\
\hline ACTIVE ACCOMPLISHMENT & $\begin{array}{l}\text { do }^{\prime}\left(\mathrm{x},\left[\text { predicate }^{\prime} 1(\mathrm{x}) \text { or }(\mathrm{x}, \mathrm{y})\right]\right) \boldsymbol{\&} \\
\text { INGR predicate } 2(\mathrm{x}) \text { or }(\mathrm{x}, \mathrm{y})\end{array}$ \\
\hline CAUSATIVE & $\begin{array}{l}\alpha \text { CAUSE } \beta, \text { where } \alpha \text { and } \beta \text { are logical } \\
\text { structures of any type }\end{array}$ \\
\hline
\end{tabular}

The Linking Algorithm comprises two main phases. The first one lies in determining which arguments in a sentence bear macroroles and which do not.

The concept of a macrorole is central to RRG. It is used instead of a large number of thematic roles. The Actor macrorole is assigned to the most agentive (in quite a classical sense, see e. g. DeLancey 1984) participant of the clause. The Undergoer macrorole is assigned to the less agentive participant of the clause. One might find helpful the correspondence between macroroles and arguments of logical structures listed in Table 1. It is captured by the Actor-Undergoer Hierarchy (Van Valin Jr. 2005: 126) in Table 2:

Table 2: The Actor-Undergoer Hierarchy (Van Valin Jr. 2005: 126)

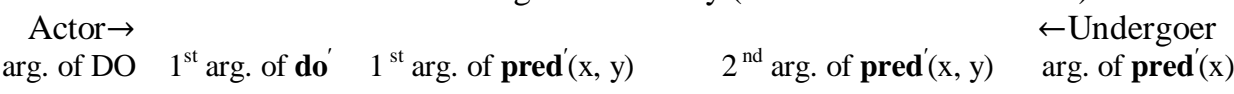

There are several tests used for determining whether an argument bears a macrorole. Most often, the passivization test is used. The idea is that only the argument that does bear the Undergoer macrorole can become the subject of the passive construction (or, in RRG terms, the "privileged syntactic argument").

Various verb alternations lead to the reassignment of macroroles. Consider the English dative-shift construction (the label NMR stands for the non-macrorole participant).
a. John gave a book to Mary.
Actor Undergoer NMR
b. A book was given to Mary by John.
(2) a. John gave Mary a book.
Undergoer NMR Actor
Actor Undergoer NMR
b. Mary was given a book by John.
Undergoer MR. Actor 
In (1a), the direct object is the Undergoer macrorole bearer. The passive test in (1b) confirms this. In (2a), however, it is not clear which argument is the Undergoer. As only the structure like (2b) is possible, the only macrorole assignment is presented in the (2a) annotation. One can see that in (1), the participant Mary had no macrorole and got one in (2). The opposite is observed for the participant book that had borne a macrorole in (1) but was demoted to a non-macrorole position in (2). The dative shift can thus be formulated as a construction that promotes the NMR argument to the Undergoer's position (see also Van Valin Jr. 2005: 121).

Once the macroroles are determined, the second phase of the linking between the two representations commences. Now, morphological cases in the syntactic structure can be associated with the semantic structure. As case marking is not universal and depends on the alignment type characteristic to a particular language or even a particular construction, there are several rules formulated for this step. In this paper, we are looking at languages with accusative alignment, so the rule for the basic case assignment is shown in (3) (Van Valin Jr. 2005, ex. 4.25).

a. Assign nominative case to the highest-ranking macrorole argument (in terms of Table 2).

b. Assign accusative case to the other macrorole argument.

This rule covers intransitive and transitive constructions having at most two participants. As causative constructions can contain three participants, specific rules for assigning a case to non-macrorole arguments are needed at the following step of the linking.

Van Valin Jr. (2007: 42, ex. 12) suggests one default non-macrorole case assignment rule, see in (4).

(4) a. Assign INS to non-MR $b$ argument if, given two arguments, $a$ and $b$, in a logical structure, with (1) both as possible candidates for a particular macrorole and (2) $a$ is equal or higher on the AUH (Table 2), $b$ is not selected as that macrorole.

b. Assign DAT to non-MR direct core arguments (default) ${ }^{2}$.

The important thing about this rule is that it describes specific usage of the ablative case and assumes dative to be the default (obviously, it applies to only those languages where the mentioned cases are identifiable). We will see, however, that some constructions may not demonstrate the relationship between INS and DAT in a form that is described in (4).

The above-mentioned rules are all claimed to be universal (or as universal as possible). However, it is acknowledged that language-specific rules can intervene at any

\footnotetext{
${ }^{2}$ In RRG, all arguments required by the logical structure of the predicate are considered core arguments. The term "direct" refers to "core arguments which are either unmarked, as in English, or marked by case alone, as in Icelandic” (Van Valin Jr. \& LaPolla 1997: 29).
} 
stage of the linking algorithm. The reason for that is that in some languages, there are constructions that override the generic rules. In order to capture "the idiosyncratic, language-specific features of constructions" (Van Valin Jr. 2005: 132), a module of constructional schemas has been added to RRG. One might see it in Figure 1 as an enrichment source for the Linking algorithm. Although several examples of constructional schemas are given in Van Valin Jr. (2005) and some other papers, their internal structure is far from being standardized. Nevertheless, constructional schemas are a powerful device that allows incorporating language-specific information into a generalized analysis.

In order to draw a "clear distinction between declarative and procedural elements", Osswald \& Kallmeyer (2018) suggested a formalization of Role and Reference Grammar. They suggest using features instead of performing a step-by-step analysis. Hierarchies like Table 2, as well as all the information provided in a constructional schema, can be encoded as features born by syntactic or semantic constituents. Due to the unification process (features with the same values match), grammatically correct structures are produced, and ungrammatical structures are rejected.

\subsection{Approaches to causatives within RRG}

Causative constructions have been studied in RRG for a long time. In this section, we summarize and comment on some central claims, without trying to give an exhaustive review of all available studies.

Causative constructions can be construed as complex predicates (junctures in RRG terms). A detailed description of alternative case marking in causative constructions is given by Foley and Van Valin Jr. (1984). The most frequently cited example is a French periphrastic causative construction, as in (5):

(5) a. Je fai-s mang-er les gâteau-x à Jean

1SG make-PRS.1SG eat-INF DET.PL biscuit-PL to Jean

'I made Jean eat the biscuits.'

b. Je fai-s mang-er les gâteau-x par Jean

1SG make-PRS.1SG eat-INF DET.PL biscuit-PL by Jean

'I had Jean eat the biscuits.'

A similar construction of Spanish has been extensively investigated by Paris (1999). Another study dedicated to causative constructions which uses the RRG framework is Park (1993).

\subsubsection{The volitionality hypothesis}

Morphological causatives, in contrast, have not been studied much within the RRG framework. An extensive comment on a morphological causative construction is given in Foley and Van Valin Jr. (1984: 384). The treated example from Kannada (Dravidian) is repeated here as (6): 
(6) a. Avanu- $\varnothing$ nana-ge bisket-annu tinn-is-id-anu

3SG-NOM 1SG-DAT biscuit-ACC eat-CAUS-PST-3SG.M

'He fed me a biscuit.' or 'He made me eat a biscuit.'

b. $\quad$ Avanu- $\varnothing$ nann-inda bisket-annu tinn-is-id-anu

3SG-NOM 1SG-INS biscuit-ACC eat-CAUS-PST-3SG.M

'He had me eat a biscuit.'

The initial claim of Foley and Van Valin Jr. (1984) is that Causees receive different case marking because they are not the same in terms of volitionality. It is stated that the instrumental case marks a more volitional Causee, and the dative case marks a less volitional Causee. There is a convention to translate these two constructions with two different English serial constructions (see translations in (6) and (5)).

\subsubsection{The agentivity implicature}

Later studies of causatives within the RRG framework came up with the idea of the agentivity implicature, first discussed by Van Valin Jr. \& Wilkins (1996) and then revisited by Van Valin Jr. (2018). It is suggested that

with some verbs agentivity is not a lexical property but rather an implicature involving human (and high animate) effectors... In the implicature case, human effectors may be interpreted as acting willfully and volitionally in the absence of evidence to the contrary; the agentive interpretation can be blocked" (Van Valin Jr. 2018: 125).

The implicature grounds on a pragmatic principle formulated by (Van Valin Jr. \& Wilkins (1996: 309) as follows: "You may interpret effectors and effector-themes which are humans as agents (in the absence of any information of the contrary)".

The two possible interpretations of a sentence are thus formulated in the form of "blocking" or "favoring" the implicature. A "blocking" or "disfavoring" of agentive implicature in causative constructions means that interpreting the Causee as an agent is impossible (or not normal) (Van Valin Jr. \& Wilkins 1996: 311, Van Valin Jr. 2018: 127). "Favoring" the agentive implicature means that the Causee can be interpreted as an agent.

Van Valin Jr. (2018: 127) provides an analysis of alternations in Causee marking in several languages. It shows that morphological cases are not strictly assigned to one interpretation or another. For example, in Japanese and Basque, dative marking occurs in the case of favoring the implicature. But in French and Kannada, it occurs in case of disfavoring the implicature.

However, there is one tendency that is attested for all the described languages. Suppose one compares which constituents (in terms of the accessibility hierarchy (Keenan \& Comrie 1977: 66), see (7)) cases used for the Causee mark prototypically. The case used for marking the Causee in the situation when the agentivity implicature is disfavored is the one prototypically used for constituents located higher in the accessibility hierarchy than the case in the situation of the favored implicature. 
Subject $>$ Direct object $>$ Indirect object $>$ Oblique object $>$ Genitive (Possessor) $>$ Object of comparison

Examples would make this observation clear. In Japanese, the case for the Causee in the situation of a disfavored implicature is accusative, which is prototypically used for marking direct objects. Once the implicature is favored, the dative, which prototypically marks indirect objects, is used. When dative is used with a disfavored implicature (as in Kannada), the instrumental case is used in the situation favoring it. Instrumental prototypically marks oblique objects, so the trend holds for this pair of cases as well.

The agentivity implicature hypothesis is somehow in line with the volitionality hypothesis. If the implicature is favored, the Causee is interpreted as an agent, and, thus, it is volitional.

\section{Data}

\subsection{A short introduction}

Altaic is a macrofamily of languages, encompassing three main families (Turkic, Tungus(ic) and Mongolian ${ }^{3}$. All Altaic languages are agglutinating, strongly dependent-marking, follow the basic SOV word order and nominative-accusative alignment. The variation among languages in one family is minimal, which leads to interintelligibility, on the one hand, and quite a number of comparative linguistic studies, on the other hand (of which Smetina 2016 is most significant for the present paper). Bashkir and Kalmyk, the languages this paper is about, are spoken in autonomous republics within Russia. This is why each of these languages experiences a strong influence from Russian. However, while there are many people for whom Bashkir or Kalmyk is the mother tongue, many speakers are bilingual.

Grammars of Bashkir and Kalmyk have been written in Soviet times. Although remarkably useful, today, these volumes seem outdated. The main reason for that is the fact that they contain prescriptive norms instead of describing the facts. Besides, an inevitable language change has taken place during the last years. For this reason, there have been several fieldwork studies during the recent years supported by the Russian Academy of Science. The papers built on field reports about Kalmyk causative constructions (Say 2009) and Bashkir causative constructions (Perekhval'skaya 2017) constitute the point of departure for the present paper. Both these papers are written in a robust functionalist perspective. They use concepts of verb classes and thematic roles, combining well with the key concepts of RRG. Both authors also provide a significant number of language examples with extensive interpretative comments. Thanks to that, raw data and some conclusions are easy to access at the same time.

\footnotetext{
${ }^{3}$ The question whether to include Korean and Japanese languages in the Altaic family is still debated but has no importance for the present paper.
} 


\subsection{Material}

In this section, the fundamental properties of the constructions with a morphological causative in Kalmyk (Say 2009) and Bashkir (Perekhval'skaya 2017) are described.

\subsubsection{Bashkir}

There are two productive causative suffixes in Bashkir: -(a)t and -dar. The choice between them is motivated in most cases by morpho-phonological reasons. There are also several non-productive suffixes, some of which are already fused into the verb stem. It is sometimes claimed that infinite chains of causative suffixes are possible (in this case, fossilized morphemes will always precede productive ones), but in reality, verbal forms with three or more causative suffixes are avoided by the speakers even in the elicitation task (Perekhval'skaya 2017: 238).

In any Bashkir causative construction, the Causer occupies the highest syntactic position and is marked with the nominative case marker. The object influenced by both the causing and the caused event (we will call it the Theme hereafter) always occupies the lowest position and is assigned the accusative case.

The Causee can receive dative ((9) and (10)) or ablative (8) marking.

Ataj bala-lar-ðan jeläk jəj-ðər-a

father child-PL-ABL berry pick.up-CAUS-IPFV

'Children are picking up berries because of the orders of the father.'

Lit. 'The father makes the children pick up berries.'

Bala besäj-gä höt-tö es-er-ä

(Perekhval'skaya 2017: 245)

child cat-DAT milk-ACC drink-CAUS-IPFV

'The child feeds the cat with the milk.'

(10) Dilä beð-gä üð-e-nen kejäw jeget-e-

(Perekhval'skaya 2017: 241)

Dila we-DAT 3.SG-POSS.3-GEN mate boy-POSS.3-GEN

foto-hə-n kür-hät-te

photo-POSS.3-ACC see-CAUS-PST

'Dila showed us the photo of her boyfriend.'

(Perekhval'skaya 2017: 243)

Although ablative might seem a surprising case in this situation, it is not unusual in Bashkir constructions involving valency modification. Namely, this is the case used for demoted agents in passive constructions.

An interesting observation about the semantics of the construction with ablative Causee marking is suggested by Bonch-Osmolovskaja (2007). Investigating Mishar Tatar (a language genetically very close to Bashkir), she points out the inadequacy of translating sentences like into Russian using verbs like 'order' (Bonch-Osmolovskaja 2007: 147, footnote). 


\author{
Mishar Tatar \\ Renat zexrä-dän išek-ne jap-trr-a \\ Renat Zukhra-ABL door-ACC close-CAUS-ST.IPFV \\ 'Renat makes Zukhra close the door.'
}

She claims that constructions like (11) imply that the caused event cannot be canceled. For example, the sentence in (11) cannot be continued with something like "but Zukhra does not obey". In terms of logical structures, we might notice that the impossibility to cancel the event is proper to verbs of the class Accomplishment (as described in Table 1). For the moment, we leave this observation without much further analysis, but we will refer to this property of causative constructions with ablative Causee marking later on.

In Bashkir, the ablative marking of the Causee is more frequent. Meanwhile, the dative marking is preferred with the so-called "verbs of transfer", as in (9). Verbs like 'show' as in (10) can also be considered as containing a verb of non-physical transfer, because in the event of showing there is something transmitted from the Sender to the Recipient.

However, there are situations in which either of the two strategies is possible. The acceptability of examples like (12) provided by Perekhval'skaya (2017: 244) indicates that the choice of the case is not determined by the verb itself, even though some correlation between the strategy of the Causee marking and the semantics of the verb can be observed. So, the observed tendency of dative marking being used with verbs of transfer is not an absolute rule. There might be other motivations for the choice of a specific morphological case for the Causee.
a.
Babaj
ul-ə-nan
xat-to uqə-t-tər-a
old.man son-POSS.3-ABL letter-ACC read-CAUS-CAUS-IPFV
'The grandfather asks his son to read the letter.'
Lit: 'The grandfather makes the son read the letter.'
b. Babaj ul-ə-na xat-tə uqə-t-tər-a
old.man son-POSS.3-DAT letter-ACC read-CAUS-CAUS-IPFV
'The grandfather lets his son read the letter.'
Lit. The grandfather has the son read the letter.'

Two slightly different translations for (12a) and (12b) indicate that there is a difference between the two constructions. The following explanation of this fact has been given by Perekhval'skaya (2017: 245):

Similarly to the situation in (12a), when the old man discovers the contents of the letter employing the son (e.g. he comes up with this solution because he has forgotten his glasses). The letter is most probably read aloud in the presence of the old man. In (12b), the son is interested in discovering the contents of the letter. He may read it on his own, in a place or time different from the situation of causation. 
If we try to interpret this judgment in more formal terms, we might need the notion of volitionality. The Causee in (13a) is described as much less volitional than in (13b). This is in line with the volitionality hypothesis in RRG (see section 1.2.1).

\subsubsection{Kalmyk}

The situation in Kalmyk is very similar. There are five suffixes considered to

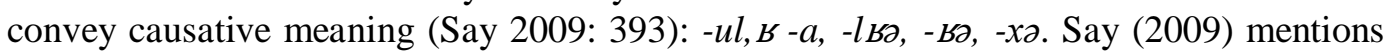
that it is possible to derive a causative from almost every Kalmyk verb. Typically, each verb combines with only one causative suffix, but several verbs allow multiple causative derivations. Although the debate about whether all the five listed morphemes are markers of a single grammatical category is still open, we follow Say (2009) and consider them all as being "just" causative suffixes. A verb (intransitive or transitive) can have two causative markers, but in this case, one of them is usually fused into the verbal stem.

In constructions with causative alternations of transitive verbs, the Causer occupies the highest position and becomes the syntactic subject (nominative case, clause-initial position), while the Theme becomes the direct object (accusative case, preverbal position). The Causee can take one of the following three cases: instrumental (13), dative ((14) and (15)), or accusative (16). The last option is discussed in section 2.3:

$$
\begin{array}{llll}
\text { ezə-n } & \text { ködəlməšč-är } & \text { xö } & \text { al-ulə-v } \\
\text { master-EXT } & \text { servant-INS } & \text { ram } & \text { kill-CAUS-PST }
\end{array}
$$

'The master made the servant kill the ram.'

$$
\begin{aligned}
& \text { ekə ürə-n-d-än xašə id-ül-žä-nä } \\
& \text { mother child-EXT-DAT-POSS.REFL porridge eat-CAUS-PROG-PRS } \\
& \text { 'The mother feeds the child with porridge.' }
\end{aligned}
$$

(Say 2009: 387)

$$
\begin{aligned}
& \text { Badma gerg-n-ännj zurəg nan-də üz-ülə-v } \\
& \text { Badma wife-EXT-GEN.POSS.3 image me-DAT see-CAUS-PST } \\
& \text { 'Badma showed me a photo of his wife.' }
\end{aligned}
$$

(16) bagšə madn-igə škol-də kögక̌mə soys-ul-na teacher we-ACC school-DAT music listen-CAUS-PRS 'At school, the teacher made us listen to music.'

(Say 2009: 411)

In Kalmyk, the instrumental case is used for demoted agents in passive constructions. Consider the example below:

$$
\begin{array}{lll}
\text { üüdə-n } & \text { Badm-ar } & \text { sekə-gdə-v } \\
\text { door-EXT } & \text { Badma-INS } & \text { open-PASS-PST } \\
\text { 'The door } & \text { was opened by Badma.' }
\end{array}
$$


This shows that although the cases used for the Causee marking are different in Bashkir and Kalmyk, they are functionally similar. Therefore, instead of speaking of two strategies of Causee marking (ablative in Bashkir and instrumental in Kalmyk), we find it appropriate to postulate the presence of one single construction in both languages. We will refer to it as "marking like the demoted agent".

It is stated in Say (2009: 406) that the native speakers strongly prefer the strategy with an instrumental case, the dative is possible in a limited number of situations, the accusative is relatively marginal. This note is critical. The fact that the dative construction is definitely not the default one in Kalmyk (and, seemingly, in Bashkir as well) contradicts the wellknown rule suggested by Comrie (1976). According to it, the Causee must occupy the leftmost available slot in the accessibility hierarchy (7) (Keenan \& Comrie 1977: 6).

Indirect objects are in the vast majority of languages realized as datives, whereas ablative and instrumental cases usually code oblique objects. Say (2009) is very concerned with this issue and offers an extensive discussion on why dative does not play the default role in Kalmyk. After having performed various syntactic tests, he discovers that the notion of indirect object is irrelevant for Kalmyk (as well as for some other languages in the world). In these languages, it is impossible to capture any syntactic difference between an indirect and oblique object. Say (2009: 400-401) comes to the conclusion that the marking of the Causee in Kalmyk constructions formed from transitive bases "does not depend on the presence of any participants except for the subject and the direct object in the structure of the base transitive verb". Dative and ablative cases fall into the same slot of the hierarchy, and the choice between them has to be justified by other reasons.

As for constructions with dative marking, Say (2009: 406) states that it is preferred in situations, where "the Causee not only becomes the central participant of the event but also receives an additional semantic interpretation as a Recipient, Addressee or Experiencer, i. e. as one of those roles that receive dative marking outside of the causative constructions". A similar trend is observed in Bashkir (see above) and correlates with the agentivity implicature postulated in RRG (see section 1.2.2).

There is another observation about the semantics of causative constructions with the dative marking. Say (2009: 407) argues that in all cases where dative marking is allowed, "the goal of the Causer is not to change the state of the participant that occupies the position of the direct object, but definitely to affect the Causee". This interpretation is entirely in line with the RRG premise that Causees marked with dative are less volitional.

\subsubsection{Summary}

As this section has demonstrated, there are two main case marking patterns in constructions with a morphological causative in the languages in question.

The default case for the Causee marking is not the dative, which would be predicted according to Comrie (1976), but the one used for marking demoted agents in passive constructions. These constructions imply the accomplishment of the caused action. The Causee in this situation is perceived as a force by means of which the Causer affects the Theme. 
Dative marking is also available, but only in some contexts. Although a preferred option in sentences with verbs of transfer, it is not the only one. Besides, dative marking appears when the action is centered on the Causee, which becomes, in turn, the mainly affected participant. The permissive reading of (12b) seconds this hypothesis, which is also in line with the idea of loss of volitionality by the Causee.

In section 3, we give our analysis of the constructions and test whether it is able to describe all the examples. In our model, we would like to explain the accomplishment reading of sentences where the Causee is marked like the demoted agent, as well as the recipient reading of the dative construction.

\subsection{Yet another construction}

In the previous section, a construction with accusative Causee marking has been mentioned. Apart from Kalmyk, as in (16), it is also attested in other Altaic languages, see (18) and (19) ${ }^{4}$ :

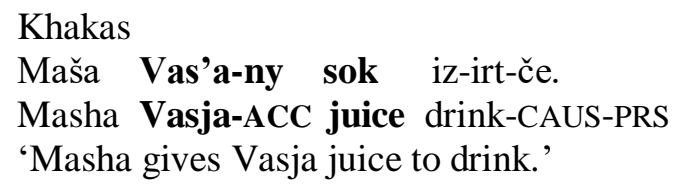

This construction is possible since Altaic languages allow differential object marking. In a nutshell, this means that a direct object can lack an overt marker of accusative case in some circumstances (a thorough description of this phenomenon can be found in Konoshenko 2009 and Garejshina 2014 a. o.).

The syntactic structure of this construction is very rigid. In causative constructions with accusative Causees, the syntactic subject has to be clause initial. There is a tendency for every subject to be clause-initial, but in these constructions, it is not just a tendency, but a strict rule. As a demoted agent, the Causee occupies the second position in a clause, immediately after the subject. It must be marked with the overt marker of the accusative case. Importantly, the Causee thus becomes the most marked constituent in terms of explicit case. The Theme always appears in an unmarked accusative case immediately preceding the verb. Again, there is a tendency towards this word order in other constructions as well, but in this situation, it becomes non-optional. Example (16) shows

\footnotetext{
${ }^{4}$ As a side note, we have to mention that, in Khakas and Tuvinian, there is no strategy of marking the Causee like the demoted agent. The accusative strategy alternates with the dative one.
} 
that other noun phrases appear between the two strictly determined positions, i.e. between the Causee and the Theme.

There are several ideas about how to explain the fact that the Causee in a construction with a transitive base verb is marked with the accusative case. We give a summary below. Kulikov (1998: 262) postulates the presence of a pseudo-DO, which lacks some important direct object properties. The presence of a pseudo-DO leads to a free position of the DO, which can thus be occupied by another argument, e. g., the Causee. Say (2009) suggests that the nouns preceding the verbs in these constructions are not fully independent, but are part of some larger unit such as a light-verb construction or an idiomatic expression. He thus suggests analyzing these entities not as a transitive verb with an argument, but rather as a single intransitive predicate (Say 2009: 411-412). A similar idea is also expressed in Kulikov (1998: 262).

We agree with these explanations and pay no further attention to this construction as our research focuses on causative constructions derived from transitive base verbs comprising three arguments.

\section{Analysis}

In this section, we present an RRG-based analysis of case marking strategies introduced in section 2.2. We perform a step-by-step linking from syntax to semantics and discuss whether all the properties attested in descriptive studies are captured accurately.

\subsection{Macrorole assignment}

As stated in Section 1.1, the first step of the linking is the macrorole assignment. It is attested that usually alternation in case marking leads to the reassignment of macroroles (consider English dative shift in (1)-(2) and a full description of French periphrastic causative constructions as in (5) in Van Valin Jr. \& LaPolla (1997: 535-536). This trend predicts that in causative construction with dative Causee marking, the Causee (and not the Theme) will be the Undergoer. This section will test this assumption and determine which argument(s) can bear the Undergoer macrorole in Bashkir and Kalmyk constructions with a morphological causative.

To perform the test for the macrorole assignment, one needs to passivize the causative verb. However, it is challenging to find a sentence with a verb with both causative and passive markers, where all the noun phrases would be explicit. Example (20) has been retrieved from a corpus of oral narratives in Bashkir:

$$
\begin{aligned}
& \text { Stäw-ðä unəท urən-ə Bäläkäj Boyaðaq } \\
& \text { first-LOC that.GEN place-POSS.3 small Bugodak } \\
& \text { kül-e buj-ə-nda kür-hät-el-gän inde } \\
& \text { lake-POSS.3 length-POSS.3-LOC see-CAUS-PASS-PTCP.PST yet } \\
& \text { 'Then its place was shown near the lake Small Bugodak.' }
\end{aligned}
$$

(Ovsjannikova et al. 2019) 
The predicate contains the verb root kür 'see', which also occurs in (10). This verb can have a semantic interpretation of a "non-physical transfer". Thus, in an active causative construction, dative Causee marking would be much more likely with this verb than the ablative. So, if the macrorole reassignment had taken place, in the passivized construction, the Causee (and not the Theme) would have become the syntactic subject (in RRG terms, the PSA, i.e. the privileged syntactic argument). In fact, it is not the case. The inanimate noun 'place' can only be a Stimulus of the verb 'see', not the Experiencer. Concerning causative constructions, it means that the noun 'place' can never be the Causee, but only the Theme. So, the test shows that in Bashkir, the Undergoer macrorole always remains with the Theme participant.

The situation in Kalmyk is the same: only the Theme can be the subject of a passive clause. Say (2009) notes that, in some cases, causative constructions express meaning proper to canonical passives. One could assume that the lack of macrorole reassignment can lead to function-sharing between causative and passive constructions in Kalmyk.

The lack of macrorole reassignment is a notable property of the constructions in question. It compromises the application of further rules developed for languages where the macrorole reassignment does happen to the current case. In the next section, we suggest various ways of linking syntactic and semantic structures corresponding to causative constructions without reassigning the Undergoer macrorole.

\subsection{Various ways of linking}

Since the standard linking algorithm does not apply, alternative solutions are needed. In order to perform the best linking possible, we might examine what semantic representations are involved. In this section, we work with two main hypotheses and suggest different ways of modifying the linking algorithm.

\subsubsection{One logical structure}

What we observe is the different case assigned to the Causee. There is no explicit syntactic evidence that something else changes within the construction. Therefore, the easiest method would be to postulate the alternation of two case markers within the same construction. The present section is dedicated precisely to this question. We present a solution trying to modify the existing LA procedure minimally so that it captures as many properties of the constructions in question listed in section 2.2.3 as possible.

This solution can be realized as an additional rule on the discourse-level. As shown in Figure 1, discourse-pragmatic rules are parallel to the standard linking and, if present, override the standard rules.

If we suppose that the linking has to be done procedurally, general rules apply first, and then the discourse-pragmatic rules override them. In this situation, the LA is left almost unchanged. It is only enriched with one more step. We formulate the rule for syntax to semantics linking in (21a) and the rule for semantics to syntax linking in (21b). 
(22) a. If the Causee is encoded in the same way as a prototypical Recipient, the speaker's pragmatic intention is to underline it, and an additional step of discourse-pragmatic linking has to be taken.

b. If the speaker's pragmatic intention within the given discourse context is to underline the role of the Recipient, the Causee receives the Dative marking. Otherwise, the same case as for demoted agents in passive constructions is used.

The advantage of this solution is its simplicity. However, it has some drawbacks. First of all, the assignment of cases is done twice: at the general syntactic level and the discourse-pragmatic level. If the same logic is applied for other constructions as well, the linking will be done slowly and inefficiently. Secondly, this solution does not account for other properties of the constructions in question. Namely, it does not treat the accomplishment hypothesis properly. Thirdly, RRG tries not to formulate any generalizations in terms of thematic roles but suggests operating either on the level of logical structures or macroroles.

Therefore, we consider linking to one single logical structure improper for the constructions in question and present alternative linking schemes in the next section.

\subsubsection{Two logical structures}

Due to the drawbacks of linking the constructions in question to a single logical structure, one might explore an alternative hypothesis, namely that there are two different syntactic constructions linked to two different semantic structures. This step is legitimate, because, as shown in Table 1, the operator CAUSE can take any types of logical structures, including the complex ones.

Once adopting this hypothesis, one should postulate that it is not only the case marking of the Causee that is different but the whole construction, consisting of the predicate and the three arguments.

In this section, we formulate logical constructions for constructions with both case marking strategies: dative and like demoted agent. A crucial semantic component that is present in the latter ones and is absent in the former ones is the impossibility to cancel the caused event. In terms of verb classes, we would formalize it as an additional accomplishment component in the logical structure of the caused event.

The observation that a logical structure can be augmented with an additional accomplishment part has also been made by Osswald \& Kallmeyer (2018), exemplified by English resultative constructions. The authors note that it is the accomplishment (and not any other) component that is frequently used in alternations. They demonstrate an easy and straightforward mechanism of adding a new part in the construction within the formalized version of RRG.

$$
\text { do' }^{\prime}(\mathrm{x}, \varnothing) \text { CAUSE predicate }{ }_{t r}(\mathrm{y}, \mathrm{z}) \& \text { BECOME } \text { predicate }_{\text {intr }}(\mathrm{z})
$$


In (23), the general logical structure for causative constructions with an accomplishment augment is shown. The sole argument of the causing event, $x$, is the Causer marked with the nominative case. The second argument of the transitive predicate, $z$, bears the Undergoer macrorole and receives accusative case marking. The Causee corresponds to $y$ in the logical structure and receives the same case as the demoted agent in passive constructions. The accomplishment augment encodes the change of state of the Theme, $z$, and its presence guarantees that the caused event actually takes place and cannot be canceled.

As an example, in (23), we provide the logical structure that should be linked to sentence (11):

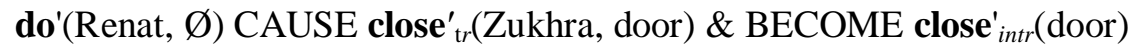

One might argue that the transitive predicate close $^{\prime}$ intr is already a lexical causative and, for this reason, already comprises an accomplishment substructure. However, we can model causative constructions derived from transitive verbs of the activity class (although a vast majority of transitive predicates appear to be accomplishments).

For that, consider the structure of (8) formulated in (24):

$$
\begin{aligned}
& {\text { do'(father, Ø) CAUSE pick.up' }{ }_{t r}(\text { children, berries) \& BECOME picked' }}_{\text {(berries }} \text { (b) }
\end{aligned}
$$

In this case, there is no assumption that all the berries become picked up immediately after the father's orders. Nevertheless, the situation of ordering entails the start of the activity of picking.

Without going more in-depth into the question of where the accomplishment part comes from, we claim that it is present in the logical structure linked to causative constructions in which Causee is marked like the demoted agent of a passive construction.

Now we aim to suggest an adequate logical structure for causative constructions with dative Causee marking. Taking into account observations from descriptive studies, summarized in section 2.2.3, we suggest perceiving predicates as in (15) also as accomplishments, but of another sort.

Consider the comments on (15) by Say (2009: 407):

What we are talking about is that the Causer's goal in these cases is not the change of state of the participant coded as the direct object, but a certain impact on the Causee. It is especially evident for verbs of the mental sphere - it is clear, for example, that in (15), the photo does not undergo any change during the causing event; there is only the change of state of the participant to whom it is shown. In (14), the porridge, of course, undergoes a significant change, but the idea of the causation is not to make the porridge vanish by means of the child, but to feed the child, i. e. make him not hungry. 
This observation leads us to the conclusion that it is the change-of-state of the Causee that is accomplished and not the change-of-state of the Theme (as above). It is in line with the claims made by Say (2009), that the Causee is the most affected participant in this clause and that the primary attention is drawn towards the Causee, not towards the Theme.

In (25), we suggest the general logical structure for Altaic causative constructions with the dative Causee marking.

$$
\text { do' }^{\prime}(\mathrm{x}, \varnothing) \text { CAUSE predicate' }{ }_{t r}(\mathrm{y}, \mathrm{z}) \& \text { BECOME predicate' }{ }_{\text {intr }}(\mathrm{y})
$$

In this structure, the assignment of nominative and accusative cases obeys to the general principles: the Causer in the syntactic structure corresponds to the $x$ argument in the logical structure, and the Theme in the syntactic structure corresponds to the $z$ argument in the logical structure. The accomplishment predicate, however, does not take the Theme as its argument, but the Causee. This is unusual, and hence the Causee receives a non-default case marking, namely, dative.

An example of a clear case of the construction of this type would be the sentence (14), which we suggest linking to (26). Again, the accomplishment predicate takes the Causee (child) as its argument.

$$
\mathbf{d o}^{\prime}\left(\text { mother, Ø) CAUSE feed } { } _ { t r } \left(\text { child, porridge) \& BECOME fed' }{ }^{\prime n t r}\right.\right. \text { (child) }
$$

Now we can explain the possibility of two different causative constructions with the same base predicate, as in (12): they have identical basic parts, but different accomplishment augments.

The logical structure for (12a) is given in (27). This structure tells that the event of reading happens immediately after the event of causing, which is exactly what Perekhval'skaya (2017: 245) comments on this structure.

$$
\text { do'(grandfather, Ø) CAUSE read' }_{t r}(\text { son, letter }) \& \text { BECOME read' }{ }_{\text {intr }} \text { (letter) }
$$

Compare it to the logical structure for (12b) given in (28):

$$
\begin{aligned}
& \text { do'(grandfather, }^{\prime} \text { (g) CAUSE read' }{ }_{t r}(\text { son, letter) \& BECOME aware.of.the. } \\
& \text { content' }_{\text {intr }}(\text { son })
\end{aligned}
$$

As Perekhval'skaya (2017) comments, sentence (12b) is used when the grandfather's goal is to make the son aware of the content of the letter. The event of reading can thus happen not immediately after the event of causing, and the son can read the letter even when the grandfather is not around. It is not meant that the son manages to read the letter somehow; the accomplishment here means that the action of reading results in a specific "change of state" of the son.

This solution seems elegant for two reasons: firstly, it reflects the key properties of dative marking in causative constructions listed in descriptive studies, and, secondly, it is parallel to the structure for constructions with Causee marked as a demoted agent. Both 
constructions correspond to the general idea that causative constructions in the given languages entail some kind of accomplishment. The fact that the accomplishment semantics interacts with causatives has been attested in other languages as well. For example, the difference between French constructions with the verb laisser 'let' is also explained with the accomplishment reading.

One might find the verb alternation where the first argument of a transitive predicate becomes the sole argument of an intransitive accomplishment predicate improbable. However, we assume that in Bashkir and Kalmyk, verbs are more flexible in their alternations than verbs in Standard Average European languages. This flexibility might be due to the alternative reference-tracking system ${ }^{5}$. In Altaic languages, speakers try to keep the noun's syntactic position throughout the discourse, using voices and verb alternations to achieve that. This is what Foley \& Van Valin Jr. (1984: 322) refer to as "switch-function" system. It is contrasted to the "switch-reference" system in Standard Average European languages, where changes of NP marking are preferred. For example, a sequence of events John enters the room and Mary notices John would entail an inflection of the pronoun in English, as in (29a). In contrast, in Bashkir or Kalmyk, a structure like (29b) will be preferred.

(29) a. John entered the room. Immediately, Mary noticed him.

b. John entered the room. Immediately, he was noticed by Mary.

The passive in the second clause helps keep the NP John in the same syntactic position as in the first clause. Smetina (2016) extensively describes this phenomenon in Bashkir, Kalmyk and Nanai and focuses primarily on the role of causative constructions in discourse.

Bearing this in mind, we suppose that the necessity to use a verb alternation occurs in Altaic languages very often; therefore, these constructions must be very productive and easy to produce and understand. This explains why the structure in (26) that seems peculiar is not as improbable as it might seem at first glance.

We claim to have proven that the idea of linking Altaic causative constructions with different case marking of the Causee to different logical structures is more appropriate than the idea to modify the single logical structure. However, the question remains, which steps of the linking algorithm have to be modified to allow this linking.

\subsection{Application}

\subsubsection{Discourse-pragmatic rules}

One way could be to formulate and apply a discourse-pragmatic rule similar to the one formulated in section 3.2.1.

\footnotetext{
${ }^{5}$ This term was introduced by Foley \& Van Valin Jr. (1984) and has not been much used afterward.
} 
Disregarding the class of the transitive base verb, any construction comprising a predicate with the caus morpheme has to be linked to the logical structure consisting of the structure do' $(\mathrm{x}, \varnothing)$ for the causing event, the CAUSE operator, and the accomplishment logical structure of the caused event. However, the exact guidelines for case assignment are different depending on the direction of the analysis. We try to formulate them in (30).

(30) a. Syntax to Semantics: If the Causee is encoded in the same way as the demoted actor in passive constructions, the intransitive predicate after the BECOME operator in the logical structure to which the syntactic construction is linked takes the Theme of the causative construction as its argument.

b. Semantics to Syntax: If the speaker's pragmatic intention within the given discourse context is to present the action as an accomplishment centered around the Theme, the Causee is assigned the same case as a demoted actor in passive constructions. If the speaker's pragmatic intention within the given discourse context is to present the action as an accomplishment centered around the Causee, the Causee is assigned the dative case.

If the linking is procedural, as suggested in Van Valin Jr. (2005), these rules are applied after the general ones. By this time, the semantic representation is already defined, and only the links between the two representations are questioned. However, with these rules, the semantic representations remain unclear until it comes to assigning the case to the Causee. This is a drawback, but rather of the procedural linking than of the discourse-rule approach.

However, if these rules can also be formulated in the form of features, as suggested in Osswald \& Kallmeyer (2018) for computational purposes, both semantic representations will be available for linking from the beginning. Subsequently, due to the constraints on the constituents, only one of them is chosen.

The formulation of the discourse-pragmatic rules is in line with the idea of the linking that an additional component may influence the default case assignment. The fact that causative constructions play an important role in the discourse organization adds some points to the hypothesis that the choice of each particular causative construction is made on a pragmatic basis. Nevertheless, the necessity to formulate two rules for two directions of linking might be regarded as a drawback.

\subsubsection{Constructional schemata}

Another source of enrichment for the Linking Algorithm is the module of constructional schemata (constructional schemas in Figure 1). They are an alternative way to encode the difference between the two causative constructions. 
As there is no standard form of a constructional schema in classical RRG, we find it appropriate to formulate just a set of constraints for each constituent ${ }^{6}$. A constructional schema can comprise information about any analysis level, including morphology, syntax, semantics, and pragmatics. The presence of syntactic and semantic information in the same structure allows using the constructional schema for the analysis in both directions. This fact is an advantage of constructional schemas in comparison to the discourse-pragmatics rules.

- Morphology

- a transitive verb with a CAUS marker

- an NP with a NOM marker

- an NP with a DAT marker

- Syntax

- an NP with an ACC marker

- Causer $=$ NP-NOM

- Causee $=$ NP-DAT

- Theme $=$ NP-ACC

- Semantics

- logical structure as in (26)

- Pragmatics

- focus on the affectedness of the Causee

Figure 2. Constructional schema for the causative construction with dative marking of the Causee

To describe the constructions we are interested in, we need to constrain several levels (or dimensions). On the level of morphology, we define the construction and list its necessary components. Morphological cases are also described at this level. So, we encode the necessity of the dative case or the one used for demoted agents in the list of morphological constraints. The syntactic dimension contains information about thematic roles and macroroles. It is identical in both constructions. The semantic dimension comprises constraints on logical structures, presented in section 3.2.2. The difference between the two constructions is in the accomplishment part. Finally, on the pragmatic level, claims about focus are made.

Importantly, constructional schemata do not contain general information relevant for several constructions in a given language. They are designed to capture individual properties of particular constructions. For this reason, for example, there is no information about the word order, as the word order in the constructions in question is standard for the languages they belong to. For the same reason, there is no information about the lack of macrorole reassignment. Although this phenomenon is not expected from the theoretical point of view, it applies to quite a range of constructions in Bashkir and Kalmyk and thus must not be encoded in the schemata for causative constructions.

\footnotetext{
${ }^{6}$ Osswald \& Kallmeyer (2018) suggest using decompositional frames for representing RRG semantic representations. A composite data structure with a syntactic tree and a decompositional frame could thus encode a constructional schema. Despite the great potential, this structure needs further development, which is not the central aim of the present paper. Therefore, we present a less formalized description.
} 
Case assignment rules for nominative and accusative are not included in the schemata as well, because they are taken from the standard Linking Algorithm without modifications.

The complete constructional schema for the causative construction with dative marking of the Causee is presented in Figure 2. It can be compared with Figure 3, the schema for the construction where the Causee is marked like the demoted agent. Note that the morphological case for the demoted agent is specified elsewhere; the present constructional schema just makes reference to that information. Also note that the pragmatic constraint on lack of specific intention enables the non-dative strategy to be the default choice, as shown in section 2.2.

- Morphology

- a transitive verb with a CAUS marker

- an NP with a NOM marker

- an NP with a case marker identical to the demoted agent

- an NP with an ACC marker

- Syntax

- Causer $=$ NP-NOM

- Causee $=$ NP-like demoted agent

- Theme $=$ NP-ACC

- Semantics

- logical structure as in (23)

- Pragmatics

- no specific pragmatic intention

- OR focus on the affectedness of the Theme

Figure 3. Constructional schema for the causative construction with the Causee marked like the demoted agent

In this paper, all constrains are postulated in a semi-formalized way, as it has no aim to produce a piece of code for the parsing engine. Encoding them as proper features in a formal metalinguistic (e. g. XMG, see Crabbé et al. 2013, Petitjean et al. 2016) is easy, yet depending on some technical decisions.

\subsubsection{Comparing the two applications}

From the theoretical point of view, both additions to the standard Linking Algorithm, discourse-pragmatic rules and constructional schemata, are legitimate. Both of them can explain the peculiarities of Altaic causative constructions without redefining general rules. Discourse-pragmatic rules require different formulations for the two directions of linking, but each rule captures the alternation between the two constructions. In contrast, constructional schemata are applicable for both directions being static feature structures but describe one construction each.

We find constructional schemata a better solution for modifying the linking algorithm not only because they are better compatible with the computational resources built upon RRG, but also because they access other modules of RRG and make the whole architecture linked tighter. Semantic representations are already built in the semantic dimension of constructional schemata. As for the syntactic representations, they can be decorated with features that would unify with general linking rules and constructional schemata. 
Consider syntactic representations Figure 4 and Figure 5 that are supposed to be linked to Figure 3 and Figure 2 respectively. All leaf nodes are assigned features that can, if necessary, percolate to the upper levels of the tree. For the sake of clarity, we have included only features relevant for the linking process.

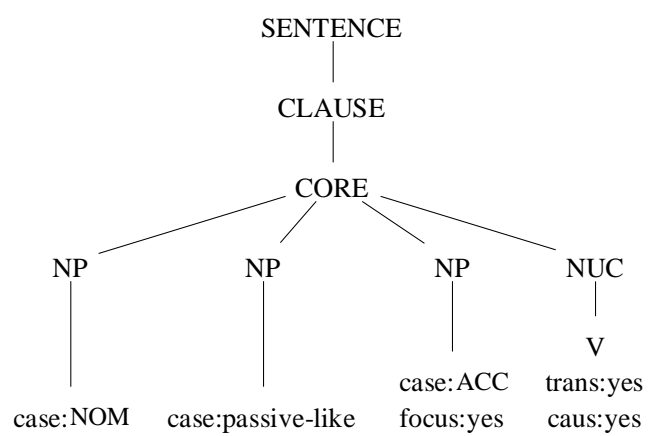

Figure 4. A tree to be linked to Figure 3

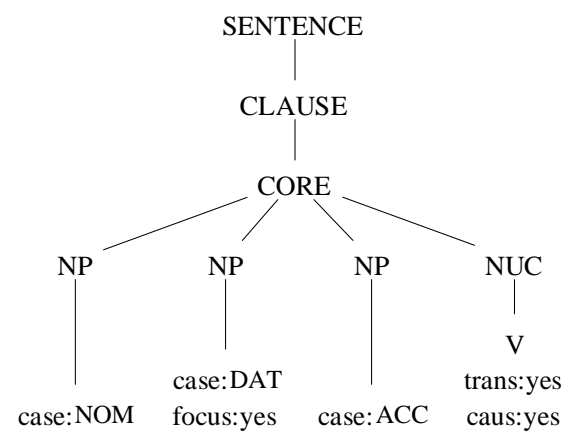

Figure 5. A tree to be linked to Figure 2

Now, we outline the complete linking process. Although we use procedural rhetoric, the feature matching is done all at once. Let us consider sentence (13a) first. It is represented as Figure 4. It comprises the predicate with a causative marker and a transitive base. These features confirm the requests for both constructional schemas Figure 3 and Figure 2, so both of them are invoked. Then, the cases of NPs in the syntactic representations are matched with the cases requested by the schemas, which leaves the only solution - Figure 3. Afterward, the linking of each particular NP to each particular slot in the logical structure is done according to Table 2 and other general rules formulated in the classical LA. Finally, the sentence (12a) gets linked to (27), with help of a syntactic representation Figure 4 and the constructional schema Figure 3. Similarly, (12b) represented as Figure 5 is linked to the logical structure (28) through Figure 2.

So, the complete linking process with constructional schemata is effective and quick and reflects all the necessary theoretical concepts.

\section{Conclusions}

We have determined that constructions with a morphological causative in some Altaic languages demonstrate different case-assignment patterns without macrorole reassignment. This gives us the right to postulate two different constructions and claim that not only the case-assignment pattern but also the semantic and the pragmatic meaning are different.

We have also determined that both causative constructions imply the accomplishment of the caused event. The difference is in the scope of accomplishment. In construction where the Causee is marked like the demoted agent of a passive construction, the accomplishment predicate takes the Theme as its argument. In contrast, in constructions with the dative marking, the Causee is the argument of the accomplishment predicate. This generalization supports observations made in fieldwork 
studies. Moreover, it seems to be related to some profound discourse organization principles in the languages in question.

We finally suggest using constructional schemas to encode each of the constructions and use them for linking. This is the most powerful device able to capture all the differences, which is also quite easy to implement.

The implementation that we suggest is based on feature assignment and is done easier and faster than the traditional linking.

Further steps of this study would be to develop a complete implementation of the new linking scheme as well as formulate similar constructional schemata for other constructions. This would lead to further refinement of RRG as a theoretical framework for studying three-argument constructions and contribute to computational solutions based on it.

\section{References}

Bonch-Osmolovskaja, A. 2007. Semantika aktantnyx derivacij. In E. A. Lyutikova, K. I. Kazenin, V. D. Soloviev \& S. G. Tatevosov (eds.), Mišarskij dialekt tatarskogo jazyka: Očerki po sintaksisu $i$ semantike, 143-191. Kazan: Magarif.

Comrie, B. 1976. The syntax of causative constructions: cross-language similarities and divergences. In M. Shibatani (ed.), Syntax and Semantics: The Grammar of Causative Constructions, 261-312. New York: Academic Press.

Crabbé, B., Duchier, D., Gardent, C., Le Roux, J \& Parmentier, Y. 2013. XMG: Extensible metagrammar. Computational Linguistics 39 (3): 591-629.

DeLancey, S. 1984. Notes on agentivity and causation. Studies in Language 8 (2): 181-213.

Foley, W. \& Van Valin Jr., R. D. 1984. Functional Syntax and Universal Grammar. Cambridge: Cambridge University Press.

Garejshina, A. R. 2014. Mnogofaktornyj podxod k variativnomu padežnomu markirovaniju (na materiale differencirovannogo markirovanija prjamogo ob'ekta i posessora $\mathrm{v}$ baškirskom jazyke). In $\mathrm{O}$. $\mathrm{V}$. Kuznecova, A. P. Vydrin, D. B. Gerasimov, N. M. Zaika, I. A. Kagirov, S. B. Klimenko, D. F. Mišenko, S. A. Oskolskaja, S. S. Saj, E. N. Sergeeva \& M. A. Xolodilova (eds.), Odinnadcataja Konferencija po Tipologii i Grammmatike dlja Molodyx Issledovatelej, 39-41. Sankt Petersburg: Nestor-Istorija.

Keenan, E. L \& Comrie, C. 1977. Noun phrase accessibility and universal grammar. Linguistic inquiry 8 (1): 63-99.

Konoshenko, M. 2009. Differencirovannoe markirovanie ob'ekta v kalmyckom jazyke Acta Linguistica Petropolitana. Works by Institute of Linguistic Studies 2: 347-386.

Kulikov, L. 1998. Causative constructions in Tuvinian: Towards a typology of transitivity. In L. Johanson, É. Á. Csató, V. Locke, A. Menz \& D. Winterling (eds.), The Mainz Meeting: Proceedings of the Seventh International Conference on Turkic Linguistics. 258-264. Wiesbaden: Harrassowitz Verlag.

Letuchiy, A. 2006. Case marking, possession and syntactic hierarchies in Khakas causative constructions in comparison with other Turkic languages. In L. Kulikov, A. L. Malchukov \& P. de Swart (eds.), Case, Valency and Transitivity, 417-439. Amsterdam/Philadelphia: John Benjamins.

Osswald, R. \& Kallmeyer, L. 2018. Towards a formalization of Role and Reference Grammar. In R. Kailuweit, E. Staudinger \& L. Künkel (eds.), Applying and expanding Role and Reference Grammar, 355-378. Freiburg: Albert-Ludwigs-Universität.

Ovsjannikova, M., Saj, S. S., Smetina, A. S. \& Aplonova, E. S. 2019. Ustnyj korpus baškirskogo jazyka der. Raxmetovo Baimovo. Saint Petersburg and Moscow. https://linghub.ru/oral_bashkir_corpus.

Paris, L. A. 1999. The Spanish Causative Construction 'Hacer-Infinitive'. A Role and Reference Grammar Description. Qualifying Paper. The State University of New York at Buffalo.

Park, K-S. 1993. Korean causatives in Role and Reference Grammar. MA thesis, State University of New York at Buffalo. 
Perekhval'skaya, E. V. 2017. Kauzativnye konstrukcii v baškirskom jazyke. Acta Linguistica Petropolitana. Works by Institute of Linguistic Studies 13 (1): 231-254.

Petitjean, S., Duchier, D. \& Parmentier, Y. 2016. XMG 2: Describing description languages. In M. Amblard, P. de Groote, S. Pogodalla \& C. Retoré (eds.), Logical Aspects of Computational Linguistics, 255272. Berlin, Heidelberg: Springer

Say, S. 2009. Argumentnaja struktura kalmyckix kauzativnyx konstrukcij. Acta Linguistica Petropolitana. Works by Institute of Linguistic Studies 2: 387-464.

Smetina, A. 2016. Kauzativnye konstrukcii i podderžanie referencii v svjaznom tekste (na materiale kalmyckogo, baškirskogo i nanajskogo jazykov). BA thesis, Saint-Petersburg State University.

Van Valin Jr., R. D. 2005. Exploring the Syntax-Semantics Interface. Cambridge: Cambridge University Press.

Van Valin Jr., R. D. 2007. The Role and Reference Grammar analysis of three-place predicates. Suvremena lingvistika 33 (63): 31-63.

Van Valin Jr., R. D. 2018. Dative case and oblique subjects. In J. Barðdal, N. Pat-El \& S. M. Carey (eds.), Non-Canonically Case-Marked Subjects. The Reykjavík-Eyjafjallajökull Papers, 115-131. Amsterdam/Philadelphia: John Benjamins Publishing Company.

Van Valin Jr., R. D. \& LaPolla, R. J. 1997. Syntax: Structure, Meaning, and Function. Cambridge: Cambridge University Press.

Van Valin Jr., R. D. \& Wilkins, D. P. 1996. The case for 'effector': Case roles, agents, and agency revisited. In M. Shibatani \& S. A. Thompson (eds.), Grammatical Constructions. Their Form and Meaning, 289-321. Oxford: Clarendon Press.

Vydrina, A. 2009. Upotreblenie pokazatelja passiva v kalmyckom jazyke. Acta Linguistica Petropolitana. Works by Institute of Linguistic Studies 2: 347-386. 